\title{
Modernidade dramática em dois tempos: Carlos Alberto Soffredini e uma homenagem a Nelson Rodrigues
}

\author{
Elen de Medeiros ${ }^{1}$ \\ Maria Emília Tortorella ${ }^{2}$
}

\section{Hibridização e modernidade: o drama moderno brasileiro em dois tempos}

Existem vários indícios que nos levam a estreitas relações entre Vestido de noiva (1943), de Nelson Rodrigues, e De onde vem o verão (1989-1990), de Carlos Alberto Soffredini. Dramaturgos de épocas distintas, ambos pensaram a modernidade do teatro brasileiro tendo como ponto de partida um fator em comum: o questionamento da forma dramática tradicional. Em 1943, ano da estreia da mais festejada peça do dramaturgo pernambucano, esse movimento era ainda novo, mas premente, dada a situação da forma dramática naquele momento: encerrada no padrão das comédias de costumes, repetia-se comumente a estrutura de convenção de apresentação, desenvolvimento e conclusão linear da fábula. Já no final da década de 1980, quando Soffredini se propõe a desenvolver um estudo do melodrama, a postura de questionamento se coloca sob outro prisma, agora repensando o próprio teatro moderno brasileiro e abrindo as portas para a forma dramática contemporânea. Ao observarmos as obras em questão, entendemos o texto de Soffredini como uma retomada respeitosa do drama rodriguiano, na medida em que o autor se ampara em recursos estilísticos bastante semelhantes aos de Vestido de noiva para a formulação de sua peça.

O drama moderno no Brasil se desenvolveu aos poucos, entre muitos embates com uma tradicional condição cênica, marcada pela presença de atores profissionais e dinâmicos. Em 1933, Oswald de Andrade canaliza sua composição dramática em confronto com o formato das comédias de costumes então vigentes, cuja estrutura estava condicionada ao modus operandi cênico, fechada em um formato predeterminado. Oswald partiu de sua contundente ironia a fim de elaborar a desestruturação do drama, rompendo e confrontando o paradigma dramático. O que Oswald coloca

\footnotetext{
${ }^{1}$ Doutora em teoria e história literária e professora da Universidade Federal de Minas Gerais (UFMG), Belo Horizonte, MG, Brasil. E-mail: elendemedeiros@ hotmail.com

${ }^{2}$ Doutoranda em artes da cena na Universidade Estadual de Campinas (Unicamp), Campinas, SP, Brasil. E-mail: emilia.tortorella@gmail.com
} 
é um jogo sarcástico com o teatro vigente, desconstruindo o estabelecido a partir de uma forma paródica.

O drama moderno, segundo Szondi (2011) e Sarrazac (2002; 2012a; $2012 b$ ), vai se desenhar a partir do rompimento da forma dramática absoluta - nos termos szondianos - ou do drama-na-vida - nos termos de Sarrazac. Isso ocorre segundo algumas vias, na dramaturgia europeia, e se consolida no Brasil a partir de outros caminhos. No entanto, o princípio do questionamento se coloca, tal como observa Szondi (2011, p. 21):

Porque a forma de uma obra de arte tem sempre algo de inquestionável, o conhecimento de tal enunciado formal só é em geral alcançado por uma época em que o antes inquestionável é posto em questão, e em que o naturalmente aceito passou a ser um problema.

É nesse sentido, portanto, que a modernidade dramática é entendida aqui. Em um primeiro momento, Szondi compreende que a inserção do elemento épico no seio da forma dramática absoluta provoca a ruptura dos principais paradigmas que a formam: a relação inter-humana, o diálogo e o tempo presente. Jean-Pierre Sarrazac (2012a, p. 32), mais recentemente, observa a forma dramática moderna como "a forma mais livre (que não é ausência de forma). $\mathrm{O}$ teatro, o drama forçando suas próprias fronteiras, levado para fora de si mesmo", libertando-se daquilo que ele chama de "pele desse 'belo animal', na qual, desde as origens, quiseram encerrá-lo".

Entre nós, ainda na década de 1920, Alcântara Machado pensou o teatro moderno a partir da bagunça: "um teatro bagunça da bagunça sairá" (Machado, 2009, p. 377). Não à toa, Oswald de Andrade parte justamente da concepção de um teatro bagunça para compor seu Rei da vela. Essa "bagunça" é marcada, entre vários dos autores nacionais, pelo hibridismo genérico, pela composição em patchwork e pela formulação de uma forma dramática mais livre.

Não cabe aqui pontuar todas as propostas de modernização de nosso teatro (desde Roberto Gomes, Renato Vianna, passando por Alcântara Machado, Álvaro Moreyra e Alfredo Mesquita, até Oswald de Andrade ou Nelson Rodrigues), mas talvez seja importante marcar tais propostas como oriundas de um pensamento de renovação e modernização dramática estimuladas por uma convivência com experiências europeias. Ao longo de cerca de 30 anos de proposições diversas, as experimentações em caráter de fragmentos e de hibridismos criam corpo 
na cena nacional e abrem espaço para as propostas levadas a cabo na década de 1940.

$\mathrm{O}$ que então caracterizaria o moderno na dramaturgia nacional? Se pensarmos a produção teatral da primeira metade do século XX, iremos nos deparar com uma proposição embasada especialmente no questionamento e confronto da forma tradicional, aquela que se consolidou com as comédias de costumes, mais particularmente da Geração Trianon. Esse movimento, que teve na trilogia de Oswald de Andrade o estopim, expande-se com a obra dramatúrgica de Nelson Rodrigues, já que ambos partem justamente desse padrão das comédias de costumes e desenham um projeto estético embasado na ironia, na desestruturação e na subversão dos elementos tradicionais. Ou seja, aquilo que confere um fechamento da forma dramática - a representação de uma ação no presente em forma de diálogos - é pouco a pouco colocado em questão, já que os dramaturgos a desconstroem.

Salvaguardando as especificidades do drama nacional, e de nosso contexto, há de se considerar o exposto por Sarrazac (2002, p. 36) como um ponto de partida para a reflexão: "a modernidade da escrita dramática decide-se num movimento duplo que consiste, por um lado, em abrir, desconstruir, problematizar as formas antigas e, por outro, em criar novas formas", sem no entanto se ater ao todo, mas ao detalhe: "Porque toda sua [do dramaturgo] atenção está concentrada no detalhe da escrita, na escrita do detalhe. E o detalhe, como é sabido, significa originariamente divisão, converter em pedaços" (Sarrazac, 2002, p. 37).

Nesse sentido, se observarmos a tessitura dramática de Vestido de noiva e De onde vem o verão, o ponto de partida se dá justamente na matriz melodramática, uma forma convencional, voltando-se no entanto para sua reescrita, para um despedaçamento da estrutura para enfim uni-la novamente, sob outro aspecto, um novo drama. Ao propor a subversão dos elementos paradigmáticos do teatro, Nelson Rodrigues rompeu as estruturas, deixando antever seu projeto estético moderno - marcado pela desestruturação das formas tradicionais para em seguida reconstruí-las em formas mais abertas -, naquele momento pouco delineado, mas já apontando uma poética que se consolidou em sua trajetória teatral. Em Vestido de noiva nada é convencional: seja a composição das personagens variantes da mente alucinada de Alaíde -, seja a disposição dos espaços e a transposição dos tempos entre o passado remoto (1905), o passado recente e o presente (1943). As vias estéticas escolhidas apontam para a 
explosão dos limites dramatúrgicos, num movimento de repensar a própria concepção de arte dramática da década de 1940.

O que ora propomos é uma observação da forma dramatúrgica em De onde vem o verão, de Carlos Alberto Soffredini, justamente a partir da composição em fragmentos, em um devaneio, na medida em que a peça pode ser considerada uma homenagem ao texto rodriguiano pela apropriação que faz de recursos semelhantes, mas detendo-se nesses detalhes que a caracterizam como obra de transição entre o moderno e o contemporâneo.

Nesse sentido, teríamos uma modernização do drama nacional em dois tempos, em uma fase de vanguarda e de questionamento da forma convencional, nos anos 1940, com Nelson Rodrigues; e o reposicionamento da forma moderna em si, no final dos anos 1980, com Carlos Alberto Soffredini. Juntando os autores, estaríamos diante de dois importantes nomes da literatura dramática nacional, que se propuseram a experimentações e hibridismos da forma, expandindo-a para fora de seus limites convencionais.

\section{Marlene e Alaíde, mulheres fora de seu tempo}

Em De onde vem o verão, Soffredini se detém nos devaneios de Marlene, uma mulher que foi criada para viver no conservador reduto doméstico feminino. Morando com sua velha mãe, e dotada de mãos de fada, como se diz na linguagem popular, ela costura vestidos de noiva para ajudar no apertado orçamento da pensão com a qual vivem desde a morte do pai. Desde pequena, sua janela é praticamente seu único contato - distanciado e fantasioso - com o mundo:

MARLENE - As crianças ficavam brincando na calçada... Eu ficava impressionada como elas não tinham medo... Como era bonito o riso das crianças - parecia de cristal - batendo no céu da tarde... Risos de coragem batendo no mundo pra lá da janela. ${ }^{3}$

Marlene, porém, há muito tempo não é mais criança. Todas as meninas do seu bairro se casaram, quase todas as casas da região deram lugar a grandes e modernos prédios, já existe televisão em cores. Apenas Marlene vive naquela antiga casa, em seu retrógrado universo, com sua mãe, uma

\footnotetext{
${ }^{3}$ Todas as citações de De onde vem o verão são de uma cópia mimeografada disponível no Laboratório de Textos do Departamento de Artes Cênicas da Unicamp.
} 
figura intransigente e conservadora, que passa os dias em frente à televisão, eternamente preocupada com as violetas do parapeito da cozinha e com sua receita de brigadeiro. Numa estação de verão, debruçada em sua janela, Marlene apaixona-se por Natalino, um pedreiro.

A aproximação do casal, o desenrolar do namoro e as interferências dos amigos de Marlene, Alicinha e Cacá, e da vizinha Magda na relação são os elementos que compõem a fragmentada trama do texto, que se desenvolve com recursos de explícita teatralidade e nega ao leitor ou ao espectador um enredo de entendimento único. Tal como em Vestido de noiva, aqui também estão diluídas "as fronteiras entre o real e o irreal, entre memória, alucinação e realidade, impondo ao espectador/leitor a imprecisão dos limites e dos paradigmas" (Medeiros, 2015, p. 103), o que evidencia, inclusive, que o subtítulo da peça - "devaneio em duas partes, com canções" - não é aleatório, ou apenas poético, mas uma escolha consciente do autor em não fixar gêneros dramáticos ao texto.

De onde vem o verão divide-se, portanto, em duas partes, intituladas, respectivamente, "De um arrepio na raiz de corpo" e "De onde vêm as andorinhas". Procedimento comum às obras de Soffredini, todas as cenas também têm títulos que, em geral, resumem a situação, muito embora as transições entre elas não sejam tão nítidas - afinal, o texto processa-se tal como o escorregadio e nebuloso universo imagético da lembrança e do sonho. Assim, a "lógica interna do texto é dada não pela causalidade interna, cena a cena, mas por uma compreensão de seu todo como uma unanimidade" (Lisbôa, 2001, p.146).

Antes do início da peça, o autor descreve as personagens, que ele chama de figuras:

\section{Da lembrança:}

BETO: que passava pra aula de inglês, se casou com a Regina da Dona Dolores e era a cara do Natalino;

GLORINHA: que era uma menina de morte e era a cara de Magda; uma FREIRA: de ideias pedagógicas muito avançadas e que às vezes era a cara da Alicinha, às vezes da mãe;

o PROFESSOR de português: que parece que não regulava bem da bola e era o Cacá cuspido e escarrado;

\section{Da vida:}

A MÃE: que foi fazendo crochê e ficando velha e ninguém percebeu;

ALICINHA: que era a única amiga e sempre foi muito moderna;

MAGDA: que morava bem em frente e não estava nem aí pra nada; 
o doutor CACÁ: que gostava das boas coisas da vida e acabou ficando muito amigo;

NATALINO: que queria ver o bom que pode ter na outra ponta das estradas deste mundo;

MARLENE: que naquele verão se pôs a ter devaneios na sua janela

$\mathrm{O}$ autor anuncia explicitamente a coincidência de personagens, antecipando assim, indiretamente, as sobreposições temporais, que serão constantes: as memórias e os devaneios de Marlene invadem o palco sem qualquer demarcação textual, didascálica, cênica ou interpretativa. As personagens irrompem a cena presente, que não necessariamente se passa no tempo presente, instaurando diferentes tempos e diferentes espaços, tecendo uma trama marcada por um constante ir e vir, avançando com informações que, em seguida, são retomadas para serem complementadas ou, inclusive, reconfiguradas.

Outra recorrência própria do moderno e do contemporâneo no texto de Soffredini são as súbitas transições que as personagens têm da narração para a ação dramática e vice-versa. Essas emersões épicas e narrativas vão delineando, pouco a pouco, Marlene e a trama - e isso se dá a partir do ponto de vista de personagens, que estão habitando a cena somente pelos devaneios da protagonista. Recurso, aliás, bastante expressionista, caro à dramaturgia produzida no início do século $\mathrm{XX}$, quando das relações oníricas se projetavam os fatos e as personagens para a cena, ao que já foi estreitamente alinhado Vestido de noiva (Fraga, 1998).

A primeira cena de De onde vem o verão é, na verdade, uma antecipação da situação final: um jantar entre Marlene e Natalino. Ainda não conhecemos nem o enredo, nem as personagens, mas através do diálogo podemos perceber que se trata de um reencontro após um período de ausência. Fragmento que é, essa cena inicial não tem uma conclusão: num simples transitar da mesa para a janela, Marlene instaura um outro espaço-tempo, e agora estão em cena apenas mãe e filha, que travam um diálogo - aqui e ao longo de todo o texto marcado pela falta de escuta - sobre o casamento dos vizinhos Beto e Regina. Marlene, que costura vestidos de noiva sem nunca ter vestido um, parece resignada em sua solidão:

MARLENE - (para si mesma) Não tenho raiva nem inveja: acho até bonito eles passando de mãos dadas. 
Na verdade, porém, o assunto desperta-lhe diversas sensações e latências, e a amiga Alicinha invade a cena, instaurando uma lembrança do dia de seu casamento:

ALICINHA - Já no meu casamento a Marlene não só foi como fez o vestido de noiva. Na festa ela ficô na dela, mora? Ela sempre foi assim meia caramuja... Me lembro dela do lado da mãe, comendo bem casados com luvas-brancas.... (para Marlene de luvas brancas) Garota! Tu viu o desbunde? Tá todo mundo comentando suas mãos-de-fada para a costura...

MÃE - Com a graça de Deus.

MARLENE - Ah, que nada.

Mais uma vez, ao caminhar para a janela, Marlene retorna ao seu reduto doméstico, ao qual pertencem apenas mãe e filha:

MARLENE - (indo para a janela) O verão este ano promete.

A MÃE - Eu sempre achei que a Alicinha logo ia se encaminhá.

MARLENE - (vendo, no pátio da construção, um homem acocorado ao pé do fogo) Credo, a senhora viu? Eu não tinha reparado: tão construindo um prédio bem aqui na frente! Eu nem vi quando derrubaram a casa da Dona Candinha...

Na continuidade da cena, Marlene enxerga Natalino trabalhando numa construção em frente à sua casa, mas em sua cabeça lunática o confunde com Beto. Essa visão lhe desperta sensações remotas, que trazem à cena diversas lembranças bastante confusas dos tempos de colégio (uma freira, que tem a cara de Alicinha, querendo dar aulas de orientação sexual; uma reunião no banheiro da escola, com provocações de Glorinha, a adolescente "avançadinha"), atravessadas por uma inesperada visita de Natalino à sua casa. Sua mente está em alvoroço:

MARLENE - E na raiz do meu corpo

o arrepio fez explosão

de um vermelho quente e vivo

que cobriu todo verão

Então Marlene, aquela mulher que só tinha coragem para observar o mundo de sua janela, contrata Natalino para pintar sua casa e conquista-o, aos poucos, com lanches da tarde e jantares, até oferecerlhe, finalmente, moradia e sustento para ele poder estudar e "vencer na vida". A peça, já sabemos, não se desenvolve com essa linearidade. É de forma fragmentada e através de recursos de explícita teatralidade que as 
informações vão chegando. Por exemplo, o texto oferece apenas uma cena em que Natalino é convidado para jantar, mas descobrimos tratarse de uma recorrência por meio de um diálogo entre Marlene e Alicinha. Também o momento em que Marlene oferece sustento a Natalino acontece num flashblack dentro da cena "Impressões do doutor Cacá (na sua primeira visita)", uma das mais características quanto aos recursos de sobreposição de personagens, interposição de planos temporais e passagem narração-ação.

Desde a chegada de Cacá em sua casa, Marlene presume conhecê-lo de algum lugar, até que finalmente percebe que ele é a cara do seu professor de português do tempo de colégio. Essa constatação traz à cena uma lembrança da escola e o ator que interpreta Cacá assume, então, o papel do professor:

MARLENE - Ah, do'tor Cacá, já descobri porque é que eu achava que conhecia o senhor: o senhor é o professor de português escrito e escarrado.

PROFESSOR - " "E se a alguém ainda causa pena a tua chaga, Apedreja essa mão vil que te afaga

E escarra nessa boca que te beija"

MARLENE - (com nojo) Hum...

(Augusto dos Anjos)

PROFESSOR - A senhora disse alguma coisa, Dona Marlene?

MARLENE - (Ele era o único que dizia o meu nome na classe. E não era lista-de-chamada!)

Logo após terminar esse flashback, Cacá volta ao tempo presente da cena:

CACÁ - Só mora você e sua mãe?

MARLENE - Não... É, só moramos nós duas

CACÁ - (Por esta época Natalino já mora na casa)

Subitamente, mais um nível de passado emerge na cena e, então, vemos o momento em que Marlene convidou o pedreiro para morar em sua casa e pagar seus estudos concretizar-se em ação. Mas a cena volta para seu tempo presente, com Cacá preparando-se para ir embora quando entra Natalino:

(Vem Natalino, livros debaixo do braço. Tem aparência bem mais cuidada! Ele e Cacá dão de cara.)

NATALINO - Noite. 
CACÁ - (É essa a primeira vez que eu vejo Natalino. Mas dá pra percebê que ele já está bem familiarizado com a casa. E é tão de relance que nem dá tempo da Marlene nos apresentá, se é que ela pretendia fazê isso)

(E se vai)

E assim o namoro de Marlene e Natalino vai acontecendo: enquanto ele estuda e se adapta cada vez mais às marcas da classe à qual agora está inserido - até o seu linguajar se modifica, absorvendo as gírias e expressões contemporâneas -, ela continua em seu reduto, alheia ao mundo exterior, a não ser pelas visitas que recebe e pelo que acompanha de sua janela.

Apesar de todos esses procedimentos citados, durante a primeira parte da peça, não há um acontecimento que rompa com a possibilidade de o espectador acreditar que assiste à história do romance do pedreiro e da costureira. Mesmo quando o texto explicita que é a mente em delírio de Marlene que está guiando uma cena, não é necessariamente a desconfiança da "veracidade" do acontecimento a primeira impressão que surge ao leitor/espectador, já que desde o início a forma absoluta do drama foi subvertida. A partir da segunda parte, porém, o texto rompe e despedaça as situações num mosaico de possibilidades, culminando num desfecho que faz o leitor/espectador questionar tudo o que acabou de ver - exatamente como na peça de Nelson Rodrigues.

Na cena "A segunda ausência, a visita de Cacá e as andorinhas do verão", quando Marlene descobre que os pássaros que todo verão pousam nos fios elétricos à frente de sua janela são andorinhas, ela acredita ter tido uma revelação:

MARLENE - (sozinha) Toda vida de vez em quando elas apareceram aí e se sentaram nos fios elétricos da rua. E eu nem sabia que eram andorinhas!

(Então ela olha pro lugar por onde vai vir Natalino, como se finalmente tivesse entendido tudo!)

MARLENE - Tá vendo, sua idiota? Tá vendo quanta coisa acontece bem debaixo do teu nariz sem tu sabe o que de fato elas são...?

Surge, então, Natalino, aflito, vestindo só uma toalha enrolada na cintura, retomando uma cena da primeira parte da peça, chamada "Com um baianinho de obra?!", Marlene se afasta do centro da cena para assistir ao que aconteceu - ou ao que ela pensa que se passou - 
entre o pedreiro e Alicinha enquanto ela se apressava à cozinha para verificar se algo estava queimando. O que vê é Natalino se oferecendo descaradamente para a amiga, que também não se mostra menos libidinosa:

NATALINO - (cortando) Tu pensa que eu não vejo a fome nos teus olhos.

ALICINHA - Pode gênero até sê, de repente... O único questionamento que se coloca é que quando eu tenho fome, eu escolho o que comê.

NATALINO - Não entendi!

ALICINHA - Gênero pra bom entendedor, meia palavra basta.

NATALINO - (divertido) Ah! Então é assim? Tu é que escolhe?! Taí, tu é mesmo uma mulher diferente. Eu vô saí contigo. Espere por mim. Se ela pergunta, diz que tu vai me dá uma carona, que é teu caminho.

Relembrando-se das andorinhas, Marlene volta ao tempo presente da cena:

MARLENE - Toda vida de vez em quando as andorinhas apareceram aí e se sentaram nos fios elétricos da rua, e eu nem percebi que eram elas que faziam o verão.

Entretanto, a cena faz mais um corte temporal e Marlene assiste ao diálogo entre Cacá e Natalino exatamente precedente à cena "A conversa das cigarras", em que ambos se trataram com extrema intimidade. O que ela vê, mais uma vez, é a insinuação de Natalino, dessa vez para Cacá:

NATALINO - Eu gênero ouvi dizê... di repente nunca experimentei... mas me falaru de uns cabra tipos solitário que tem por cá, e que faiz esse esquema assim de tê uns gosto diferente di repente, tá percebendo?

CACÁ - Tô percebendo sim.

NATALINO - (aproximando-se muito) Assim foi que me disseru também que esse gênero solitário sabe bem entrá numas de dá valô a um corpo de home macho di repente, que foi criado no sertão rijo...num certo nível me disseru que ele sabe valorá um corpo inté bem mais que uma mulhé, di repente... (pondo a mão de Cacá no próprio corpo).

À medida que o texto se aproxima do final, mais Marlene parece entregue aos seus devaneios. Na cena "Cancioneta das noivas", toda 
composta por canções, surgem Magda, Alicinha e Cacá vestidos de noiva, disputando Natalino, enquanto Marlene começa a vestir-se com o vestido de noiva que estava no manequim. Lisbôa considera este um quadro bastante poético, que tem o poder de resumir ou sintetizar "o caminho do próprio universo interior de Marlene, ou o universo da peça como um todo" (2001, p. 199). Nessa atmosfera fantasiosa, Natalino chega para "O jantar às oito horas", que retoma a primeira cena da peça. Porém, agora, justaposto aos diálogos quase todos idênticos aos da primeira cena, há apartes de Marlene e também diálogos seus com a mãe com informações ainda não decifráveis, conferindo um grande suspense à cena:

MARLENE - Ai, Natalino, no sonho que eu te falei

tu me dava o teu desejo

e eu me abria em janelas

e o teu verão me explodia

em plena raiz do corpo!

(olhando ele pôr um bocado na boca)

Ai que pena, Natalino

que eu tô matando o meu sonho

Cacá e Alicinha chegam à casa de Marlene, dispostos a assumirem que são amantes, e percebem que a amiga está completamente lunática. Ao tentarem entender o que se passa, é a própria Marlene quem conduz a cena para o flashback, para mostra-lhes suas razões, num procedimento que evidencia a teatralidade do texto:

ALICINHA - Na minha opinião, a situação está nos escapando e a gente não tá sei lá conseguindo estabelecer a verdade.

MARLENE - (decidindo-se) A verdade, né? A gente tem que estabelecê a verdade, tá certo? Então tá: (pegando Alicinha pelo braço e colocando-a no lugar onde aconteceu a cena que vai se repetir). Então cê fica aqui...

ALICINHA - (surpresa) Mas o que é isso?!...

MARLENE - E agora fala: mas esse rapaz não passa de um baianinho-de-obra!

(Mas Alicinha custa a entender, e olha para Cacá, pedindo socorro)

MARLENE - (fortíssima) Fala!

ALICINHA - (rápida) ... mas esse rapaz não passa de um baianinho-de-obra!

MARLENE - (no clima da cena) Ele só está morando aqui!

(Vem Natalino de repente, aflito, vestindo só uma toalha enrolada na cintura) 
NATALINO - Tem alguma coisa queimando aqui! Tô sentindo o fedô do banhe'ro...

ALICINHA - (depois de olhar algum tempo para Marlene e Natalino) Ah, entendi. Tá bom: então vamos ver como foi que aconteceu... (e se volta para Natalino)

Porém, o diálogo que se segue não é o que Marlene esperava, mas outro. Natalino humildemente confessa a Alicinha seu amor por Marlene, a qual, ainda desconfiada e pensando estar protegendo a amiga, propõe um trato: ela custearia seus estudos, contanto que ele saísse da casa da amiga e só voltasse em melhores condições. E mal a cena retorna ao seu plano presente, Marlene a conduz para o diálogo entre Cacá e Natalino, que mostra não este seduzindo aquele, mas sim pedindo ajuda para comprar um par de alianças e firmar noivado com Marlene.

Diante das diferentes versões de uma mesma situação, qual apreender como verdadeira? Marlene está confusa e a dúvida que mais a consome não é a concernente às versões dos fatos, mas outra ainda mais delicada. Na última cena da peça, enquanto as outras personagens conversam, Marlene, totalmente descolada do diálogo, repassa em voz alta a receita do Mocotó que fizera para o jantar de Natalino, até chegar na frase ápice: "Natalino, eu matei você".

Ela revela que colocou veneno no mocotó e, à medida que todos se desesperam, caminha serenamente em direção ao manequim para arrematar o vestido de noiva, repassando mais uma vez a receita, porém afirmando agora que não colocou o veneno:

MARLENE - Eu tava aqui me lembrando: Se lava bem o mocotó, se esfrega com limão, se leva ao fogo em... então eu te vi de cócoras ao pé do fogo... E só depois que eu te vi foi que vieram as andorinhas trazendo o verão, e as palavras da canção e a saudade do perfume da dama-da-noite do quintal da dona Lurdes. Depois de você é que eu fiquei sendo uma mulher com um coração. Então fiquei com medo de volta a sê só uma mulher na sua janela... e não pus o veneno!

Paira na cena uma atmosfera de aflição e incerteza: o que realmente se passou entre Natalino e os amigos de Marlene? Quais eram as verdadeiras intenções do pedreiro? E quanto a Marlene, teria uma mulher como ela coragem de envenenar o homem que ama? Se por ventura a trama havia dado indícios de resposta, o desfecho da peça dissipa-os completamente, pois rompendo com o pathos da cena e 
teatralizando a situação, Marlene, serenamente, ainda se perguntando sobre o veneno, apaga a luz de uma sala "apagando Alicinha, Cacá e Magda" e depois apaga a luz de outra sala, "apagando Natalino". E, assim, procurando respostas, encontram-se ainda mais perguntas:

A MÃE - (guardando seu crochê) Mas afinal de contas, Marlene, tu descobriu ou não descobriu quantos ovos leva o brigadeiro...? Regô ou não regô as violetas...? Pôs ou não pôs o veneno na comida?

MARLENE - (na sua janela) Ah, sei lá, mãe, como é que eu posso sabe? Quem pode garantí que tudo isso não foram só pensamentos... a Alicinha, o Cacá, a Magda... só pensamentos que eu tive aqui da janela...?

Quem sabe Natalino ao pé do fogo não foi só vontade de procurá perfume na noite, de ouví canção...

Vontade de Andorinha...

Só vontade de verão...

Quem sabe?

Como se pode observar, em muitos momentos Soffredini se reporta à dramaturgia de Nelson Rodrigues, formulando em De onde vem o verão uma homenagem a seu antecessor a partir da forma dramática de Vestido de noiva. Alaíde, tal como Marlene, é uma mulher fora de seu tempo: marcada pela memória em decomposição, ela recorre às profundas experiências não vividas, indo atrás de Clessi em 1905 em busca da reconstrução de sua história, de seu casamento e, por conseguinte, a compreensão de seus medos e desejos. Intercala, para isso, fatos ocorridos em um passado distante com momentos gerados pela alucinação e a reconstituição de sua história recente. Provenientes da mente da protagonista, os fatos e as personagens são projetados no palco e se mesclam nos tempos à medida que a narrativa cênica se desenvolve.

Para além da imagem imediata do vestido de noiva costurado por Marlene, primeiro indício de que Soffredini não desconsiderou a peça rodriguiana, outros detalhes ainda embasam essa hipótese. $\mathrm{O}$ vaivém temporal narrativo e a sobreposição de figuras são evidentes em ambos os textos. Na peça de Nelson Rodrigues, por exemplo, as figuras que surgem no plano da alucinação, justamente por serem objetos oriundos da mente alucinada de Alaíde, são repetições (ou traduções?) das relações pessoais que ela estabelece no plano da realidade. Tal qual em De onde vem o verão, 
quando as personagens de tempos diferentes interferem no tempo que não lhes é preciso, criando uma interposição narrativa.

Se em De onde vem o verão a presença de algumas cenas são indícios da mente perturbada de Marlene, deixando antever seus delírios de verão, não podemos perder de vista que essa fragmentação de uma cena, sem início e sem fim, que se repete ao longo da narrativa, também pode ser vista na peça rodriguiana. Ponto central para toda a tensão dramática é a cena do casamento de que Alaíde precisa se lembrar, a fim de que possa se reconstruir enquanto identidade. Em Vestido de noiva, assim como em De onde vem o verão, há uma cena central (do casamento/do jantar) que, apresentada pela primeira vez sem conclusão, será eixo na condução da trama, interpondo-se a outros fatos, buscando alternativas em seu desdobramento, causando expectativa e, ao mesmo tempo, dúvida no leitor/espectador. O objetivo das peças, no entanto, não é explicar a cena, mas provocar a abertura da estrutura dramática, promovendo possibilidades de leitura.

Vestido de noiva, peça que é alinhada, por alguns críticos, como símbolo da modernidade dramática no Brasil, intercala três planos narrativos para colocar em cena Alaíde, jovem de classe burguesa, que sofre com os fantasmas do seu passado recente. Diante da morte, após ter sido atropelada, revive os principais fatos que marcaram sua construção identitária: quem é ela? Se todo mundo tem um passado, ela também há de ter. Assim, com a ajuda do alter ego Clessi, ela percorre os meandros da mente em decomposição, entre os planos da memória e da alucinação, para essa compreensão de si. Conforme já observado (Medeiros, 2015), a proposta de questionamento dramatúrgico por meio da perspectiva expressionista de Alaíde torna-se tão evidente que, em certo sentido, é possível ler o próprio plano da realidade como desvario da protagonista.

Alaíde se depara com a sombra de seus medos e conflitos e precisa enfrentá-los para conseguir reconstruir sua memória. Nesse jogo de vaivém entre os acontecimentos (verdadeiros ou fictícios, e sempre recriados), ela revê seu passado recente e se projeta ao passado remoto à procura de Clessi, prostituta morta em 1905. Ao lado da meretriz de luxo, Alaíde caminha pouco a pouco até que os cacos da memória se reúnam, formando um mosaico de imagens distorcidas, muitas sem explicação, outras repetidas e recontadas, sofrendo variações conforme o momento. 
De certa forma, estamos aqui diante de uma perspectiva bastante íntima, no uso do termo que Sarrazac (2013, p. 21) faz: “O íntimo se define como o mais interior e o mais essencial de um ser ou de uma coisa, por assim dizer, o interior do interior". E se o crítico francês se debruça aqui sobre a obra de August Strindberg e o teatro expressionista, nada mais próximo do teatro de Nelson Rodrigues, especialmente em Vestido de noiva, peça de cunho marcadamente expressionista - que poderíamos, por ora, estender a De onde vem o verão. O que se vê, de maneira geral, é uma projeção do eu profundo da(s) protagonista(s) a partir de símbolos e imagens tomadas por ela(s) durante sua(s) trajetória(s), num jogo duplo de extrojeção do íntimo, criando assim tensões que permeiam a(s) peça(s).

O íntimo difere do secreto no sentido de que ele não se destina a ser ocultado, mas, ao contrário, destina-se a ser voltado para o exterior, extravasado, oferecido ao olhar e à penetração do outro que nós escolhemos. A dupla dimensão do íntimo atesta, aliás, a sua disposição de se oferecer em espetáculo (em condições, é verdade, restritivas): por um lado, relação com o mais profundo de si mesmo e, por outro, ligação estreita de si com o outro (Sarrazac, 2013, p. 21).

Ora, é nesse processo de cada vez se aprofundar em si mesma que Alaíde e Marlene vão projetar, para a cena, o conflito inerente a si e à sua relação com os outros: a irmã/a mãe, o marido/o namorado, as convenções da alta sociedade carioca/a vida além da janela, a família/os amigos. Assim, as representações em cena são nada mais do que figuras oriundas da mente alucinada de Alaíde e Marlene, o que as constitui como seres fantasmagóricos, desencarnados - fator caro à construção de personagens na dramaturgia moderna. Nessa constante fricção entre o interior e o exterior é que se configuram as principais tensões dramáticas delineadas nos textos aqui em destaque.

É também a partir desse intimo que começamos a montar o patchwork da fábula de Vestido de noiva. Não há, considerando a fragmentação da estrutura e da memória da protagonista, uma unidade que se sustente: nem da ação, nem da narrativa, muito menos da própria personagem. O que se vê são múltiplas possibilidades de leitura do jogo ficcional, que vai se expandir para um abismo de criações ensejadas pela reconstrução da memória. Assim, vão se abrindo percursos que são percorridos até certo ponto, para então retornar e reivindicar a impossibilidade dele 
diante da falsidade. Tomemos como exemplo a retomada da cena do casamento de Alaíde e Pedro, que posta e reposta em cena três vezes possibilita caminhos diversos de compreensão; ou o momento da chegada da mãe do amante de Clessi, com o atordoamento da mente de Alaíde, a mãe surge como paródias de filmes e cenas melodramáticas. São proposições de colagem cênica, que propiciam à forma dramatúrgica uma hibridização de formatos e de temas, deixando-a marcadamente moderna pela abertura de sua estrutura.

\section{Soffredini lê Nelson Rodrigues}

Soffredini é um artista que tem sua trajetória marcada pela busca por novas formas, nova escrita, nova encenação, perseguidas sempre sob a ótica da brasilidade: ou seja, um voltar-se constante àquilo que marca a teatralidade brasileira e constituem a raiz nacional almejada. ${ }^{4}$ Tal como Sarrazac descreveu o duplo movimento da escrita dramática, Soffredini alcançou o novo a partir da tradição. Por um lado, a ligação que o autor teve desde o início de sua carreira com os gêneros populares e a comédia, os quais, embora regidos por convenções tradicionais, são abertos e aptos à renovação pela condescendência ante as transformações socioculturais e as exigências do público, conferiu-lhe grande liberdade e inventividade de escrita. Por outro lado, enquanto intelectual que trabalhava com a arte popular e o teatro de convenção, o autor sempre transcendeu os gêneros com os quais dialogava, não no sentido de melhorá-los, mas de subverter suas estruturas, mergulhando a fundo no tema abordado, atento a sua teatralidade imanente e pesquisando os procedimentos formais pelos quais o tema pode ser mais bem expressado.

\footnotetext{
${ }^{4}$ Em uma entrevista Soffredini (1980) comenta o que seria, para ele, essa ótica de brasilidade: "eu já não tenho nenhuma dúvida de que não é preciso ir ver como o Peter Brook, o Grotowiski, o Bob Wilson ou os seguidores de Brecht ou do Stanislasvki trabalham para se encontrar inspiração para um bom teatro. Existe também a questão da ótica. [...] Muitos espetáculos que têm como características de experimentação e que vão buscar até no índio do Xingu a sua vestimenta, no entanto tem uma ótica importada. [...] Não é que eu ache que isso seja mau não: nada de preconceitos verde-amarelos. Mas é que eu sempre desconfiei que aqui mesmo, ali na periferia, há uma riqueza incrível de material para pesquisar, não enquanto vestimenta apenas, mas enquanto ótica mesmo. E não só na periferia, no teatro feito sob lona, mas também no folclore, nas danças dramáticas, no teatro popular aportado no Brasil bem antes das Companhias principalmente portuguesas (os "Pássaros" de Belém do Pará, os Mamulengos do Norte e Nordeste, por exemplo) [...] basta ir lá (principalmente no Circo-Teatro porque está mais a mão) com um mínimo de sensibilidade e o interesse focado não no bizarro mas no essencial, que gradativamente a tal ótica vai mudando e gradativamente a gente vai mergulhando num mundo riquíssimo de estímulos".
} 
No programa do espetáculo da peça aqui analisada, de 1990, Soffredini declara-se francamente descontente com o contexto teatral do período. Mesmo se tratando de um depoimento descompromissado, nele podemos perceber que De onde vem o verão nasceu de uma série de questionamentos, configurando-se como uma resposta do dramaturgo frente aos limites com que a dramaturgia, de tempos e tempos, se depara (ou que lhe são impostos). "E porque o verão é o tempo dos limites sentirem angústia", como Soffredini diz no programa, ele se permitiu retomar certas estruturas para avançar em seu projeto estético:

E como nos dias que correm, de obsessiva pós-modernidade, só tem nobreza o que é obsessivamente racional. Aquilo que esbarra na emoção humana foi relegado a um lugar plebeu, pondo toda arte (principalmente teatral) em risco de se tornar um teorema frio e chato! Além do mais, conotar melodrama com lágrimas piegas é de uma obsessiva falta de conhecimento. Porque o gênero melodramático é definido por uma riqueza muito maior de regras, que só fazem devolver ao teatro a sua dimensão de legítimo divertimento. [...] E durante a pesquisa eu me pus a perguntar - coisa permitida, já que era verão! - se não seria possível fazer um teatro que fizesse o público se reconhecer, sim... refletir, sim sobre a condição de ser humano no mundo de hoje - mas fazer isso tentando devolver ao teatro seu encanto, o seu papel de sedutor? - mais ou menos como as árvores preguiçosas, o céu sonolento, as cigarras cantadoras e as andorinhas que eu vejo pra lá da janela e que o verão encantou. E, para responder a essa pergunta, e já que era verão, me pus a inventar essa história (Soffredini, 2010, p. 379-380). ${ }^{5}$

A pesquisadora Eliana Lisbôa (2001) denominou o conjunto de suas peças de obra parafrásica, pois quase todas foram escritas a partir de uma ou mais obras anteriores (peças teatrais, textos literários, músicas, poemas ou até mesmo estudos acadêmicos), as quais ele utiliza como base para uma reflexão temática, expressa em outro gênero ou forma. Lisbôa, entretanto, exclui De onde vem o verão desse conjunto, pois considera que a peça não se vincula a nenhuma obra anterior. De fato, em suas peças parafrásicas, Soffredini sempre explicita a referência à(s) obra(s) precedente(s), seja por meio do título, das didascálias ou mesmo pela fala das personagens, o que não se verifica na peça aqui em questão. Porém,

\footnotetext{
${ }^{5}$ Trecho do programa do espetáculo De onde vem o verão.
} 
como já demonstramos, são muitos os procedimentos e elementos que atestam a proximidade entre a peça de Soffredini e Vestido de noiva.

Compreendemos dois caminhos principais de homenagem a Nelson Rodrigues: primeiro, pela proposição fragmentária da peça, o despedaçamento da forma dramática como um todo, rompendo então com qualquer hipótese unitária da ação, tempo ou personagem dramática; e, em cruzamento com o primeiro, o fato de Soffredini utilizar em vários momentos referências diretas aos recursos utilizados na obra rodriguiana, por um viés expressionista, mas também melodramático, e a absorção de fatores de subversão da forma teatral convencional.

Entendendo que no procedimento de construção da obra parafrásica a referência à obra anterior é sempre explicitada, e concordando com a ideia de Sarrazac de que "a reinvenção permanente do drama é profundamente solidária à invenção - ou às invenções do teatro" (Sarrazac, 2010), podemos inferir que Soffredini não se apropria do texto de Nelson para chegar a outro "gênero ou forma". Ele, na verdade, escolhe Vestido de noiva - texto que, no contexto brasileiro, se não é inaugural da subversão das estruturas paradigmáticas do teatro, foi o primeiro a ganhar uma encenação contundente - como base para seu exercício de carpintaria dramática e de questionamentos estruturais; escolha que tornam implícitas a referência e a homenagem. É dessa forma, portanto, que Soffredini faz seu diálogo, no contínuo repensar da forma dramática, dando continuidade a uma produção que marcou o moderno teatro brasileiro e direcionando seus passos ao contemporâneo, em um processo intenso de ruptura e expansão dos limites da obra dramatúrgica.

\section{Referências}

FRAGA, Eudinyr (1998). Nelson Rodrigues expressionista. Cotia: Ateliê.

LISBÔA, Eliana Tejera (2001). A teatralidade na dramaturgia lírico-épica de Carlos Alberto Soffredini. Tese (Doutorado em Teoria e História Literária) -Universidade Estadual de Campinas, Campinas.

MACHADO, Antônio de Alcântara (2009). Palcos em foco: crítica de espetáculos; ensaios sobre teatro (1923-1933); tentativas no campo da dramaturgia. Pesquisa, organização e introdução de Cecília de Lara. São Paulo: Editora da USP.

MEDEIROS, Elen de (2015). Nas trilhas da memória: um percurso pelos caminhos de Vestido de noiva. Repertório - Teatro e dança, Salvador, n. 25, p. 101-108. 
RODRIGUES, Nelson (2004). Teatro completo. 2. ed. Rio de Janeiro: Nova Fronteira, v. 1.

SARRAZAC, Jean-Pierre (2002). O futuro do drama. Tradução de Alexandra Moreira da Silva. Porto: Campo das Letras.

SARRAZAC, Jean-Pierre (2010). A reprise (resposta ao pós-dramático). Questão de crítica, v. 3, n. 19, mar. Disponível em: https://goo.gl/mz5wph. Acesso em: 2 abr. 2016.

SARRAZAC, Jean-Pierre (2012a). Léxico do drama moderno e contemporâneo. São Paulo: Cosac Naify.

SARRAZAC, Jean-Pierre (2012b). Poétique du drame moderne. Paris: Seuil.

SARRAZAC, Jean-Pierre (2013). Sobre a fábula e o desvio. Organização e tradução de Fátima Saadi. Rio de Janeiro: Teatro do Pequeno Gesto; 7 Letras.

SOFFREDINI, Carlos Alberto (1980). De um trabalhador sobre seu trabalho. Revista Teatro, São Paulo, ano 1, n. 0, jun./jul.

SOFFREDINI, Carlos Alberto (s.d.). De onde vem o verão. [S.l.]: S.n. Mimeo.

SOFFREDINI, Renata (2010). Carlos Alberto Soffredini: serragem nas veias. São Paulo: Imprensa Oficial do Estado de São Paulo.

SZONDI, Peter (2011). Teoria do drama moderno: 1880-1950. São Paulo: Cosac Naify.

Recebido em abril de 2016.

Aprovado em agosto de 2016.

\section{resumo/abstract/resumen}

\section{Modernidade dramática em dois tempos: Carlos Alberto Soffredini e uma homenagem a Nelson Rodrigues}

Elen de Medeiros

Maria Emília Tortorella

Este artigo tem como proposta aproximar De onde vem o verão (1989-90), de Carlos Alberto Soffredini, de Vestido de noiva (1943), de Nelson Rodrigues, compreendendo as múltiplas referências textuais e intertextuais existentes na peça de Soffredini. Para isso, consideram-se na obra desses autores dois 
momentos de modernidade dramática, tendo em vista as formas híbridas desenvolvidas e alinhadas aos anseios de cada época de criação.

Palavras-chave: literatura dramática, teatro moderno e contemporâneo, Carlos Alberto Soffredini, Nelson Rodrigues.

\section{Dramatic modernity in two stages: Carlos Alberto Soffredini and a tribute to Nelson Rodrigues}

Elen de Medeiros

Maria Emília Tortorella

This article aims to approach De onde vem o verão (1989-90), written by Carlos Alberto Soffredini, and Vestido de noiva [Wedding Dress] (1943), written by Nelson Rodrigues, understanding the multiple textual and intertextual references that exist in Soffredini's play. For this, two moments of dramatic modernity are examined in the work of these playwrights, taking into account the hybrid forms developed in both plays and that reflect the historical context of each playwright's work.

Keywords: dramatic literature, modern and contemporary theater, Carlos Alberto Soffredini, Nelson Rodrigues.

\section{La modernidad dramática en dos tiempos: Carlos Alberto Soffredini y un tributo a Nelson Rodrigues}

Elen de Medeiros

Maria Emília Tortorella

Éste artículo pretende acercarse a De onde vem o verão (1989-90), de Carlos Alberto Soffredini, y Vestido de noiva (1943), de Nelson Rodrigues, por medio de la comprensión de las múltiples referencias textuales e intertextuales existentes en la pieza de Soffredini. Para eso, se consideran en la obra de estos autores dos momentos de la modernidad dramática, teniendo en cuenta las formas híbridas desarrolladas y alineadas con los anhelos de cada tiempo de creación.

Palabras clave: literatura dramática, teatro moderno y contemporâneo, Carlos Alberto Soffredini, Nelson Rodrigues. 